\title{
CHITOSAN, PECTIN AND VITAMIN C AS TOOLS FOR REMOVING HEAVY METALS FROM DIETS AND ITS EFFECT ON GOATS PERFORMANCE
}

\author{
A.A. Hassan ${ }^{1}$; M.S. Khalel ${ }^{1}$; A.M. Shwerab ${ }^{1}$; M.H.Yacout ${ }^{1}$; H.M. El-Nobi ${ }^{1}$ and Y. M. \\ Gohar $^{2}$ \\ ${ }^{I}$ Department of By-products Utilization, Animal Production Research Institute, Agriculture Research \\ Center, Dokki, Giza, Egypt. \\ ${ }^{2}$ Botany Department, Microbiology Section, Faculty of Science, Alexandria University. El-Shatby, \\ 21321 Alexandria, Egypt.
}

(Received 26/5/2015, accepted 14/7/2015)

\section{SUMMARY}

I n order to study the effect of chitosan, pectin and vitamin C tools for removing heavy metals (HM's) from diets and as antioxidant and its effect on goats performance, experimental diets consisted of concentrate feed mixture (CFM) plus acacia forage irrigated with wastewater, were served as control $\left(D_{1}\right) ; D_{1}$ plus $5 \mathrm{gm} / \mathrm{head} / \mathrm{d}$ chitosan $\left(\mathrm{D}_{2}\right) ; \mathrm{D}_{1}$ plus $20 \mathrm{gm} /$ head $/ \mathrm{d}$ purified pectin $\left(\mathrm{D}_{3}\right)$ and $\mathrm{D}_{1}$ plus 500 $\mathrm{mg} / \mathrm{head} / \mathrm{d}$ vitamin C (D4). Twenty lactating Zaraibi does in the $2^{\text {nd }}$ and $3^{\text {rd }}$ season of lactation with $34.5 \mathrm{~kg}$ in average body weights were used for feeding trial. They were randomly divided into four equal groups ( 5 does each). While twelve Zaraibi bucks $50.2 \mathrm{~kg}$ weight were used in four digestion trials. For rumen fermentation trials, three does fitted with permanent rumen fistula were used. Goats were offered acacia forage ad libitum twice a day at 8.00 and 16.00 plus restricted amount of CFM to cover $50 \%$ of protein requirements according to NRC (2007). Results showed that: 1- Acacia plant had lower $\mathrm{pH}$ than that of wastewater or soil; while all HM's in acacia were higher than that in wastewater or soil; 2- Digestibility coefficients, nutritive values and nitrogen utilization of goats fed diet supplemented with pectin or vitamin $\mathrm{C}$ had significantly highest $(\mathrm{P}<0.01)$ values, followed by diet supplemented with chitosan, while control diet was recorded the lowest values. 3Ammonia-N concentration was decreased $(\mathrm{P}<0.01)$ with chitosan, pectin or vitamin $\mathrm{C}$ supplementation; while VFA's concentration was increased; 4- Molar proportion of VFA's in rumen of goats showed that acetic acid concentration was higher in $\mathrm{D}_{3}$ and $\mathrm{D}_{4}$ than other diets, while propionic acid had the highest $(\mathrm{P}<0.05)$ value with group supplemented with chitosan, and no significant difference among treatments was found respecting butyric acid concentration; 5- Pectin or vitamin $\mathrm{C}$ addition lead to an increase in ruminal bacteria numbers and their activities, not only that, but they had higher $(\mathrm{P}<0.01)$ for microbial protein $(\mathrm{MP})$ syntheses as well; 6- Milk production was significant increased with all supplemented groups and in the meantime does showed significantly better feed conversion compared with control one; 7- Serum glucose, cholesterol, urea, AST and ALT in blood were significantly $(\mathrm{P}<0.01)$ decreased by the supplementation of chitosan, pectin or vitamin $\mathrm{C}$ compared with control diet. While, serum total protein, albumin and globulin were significantly $(\mathrm{P}<0.05)$ increased; and 8- Heavy metals residues in the feces of chitosan, pectin or vitamin $\mathrm{C}$ groups was showed high values compared with the control group. But their residues in the blood serum and milk were fewer values compared with the control group. It could be concluded from this study that supplementation with chitosan, pectin or vitamin C could improve goats' performance and remove of HM's from blood and milk. However, the use of pectin or vitamin $\mathrm{C}$ could come in the first priority versus chitosan that come in the least priority.

Keywords: Chitosan, pectin, vitamin $C$, digestibility, rumen fermentation, blood analyses, milk production, heavy metals residue, waste water, lactating does.

\section{INTRODUCTION}

Environmental pollution by toxic metals occurs globally through industrial and agricultural processes and waste disposal (Duffus, 2002). Throughout Egypt, the course of irrigation and drainage canals is a total of approximately $55,000 \mathrm{~km}$. Degradation of water quality in the Nile River and associated irrigation and drainage canals is a major issue in Egypt (Abdel-Shafy and Aly, 2002). Pollutants included not only agricultural wastewater alone but also industrial wastewater and municipal wastewater as well. Major 


\section{Hassan et al.}

pollutants in agricultural drains are salts; nutrients (phosphorus and nitrogen); pesticide residues (from irrigated fields), pathogens (from domestic wastewater), and toxic organic and inorganic matters (AbdelSabour et al., 2005). The most possible sources of soil, water and plant pollutions are: sewage sludge, residues of industrial factories and intensive fertilization. Heavy metals (HM's) are considered as serious inorganic pollutants, they have toxic effects on human health, animals, plants and life in aquatic system (Nouri et al., 2011). Recently, HM's pollution in natural water has been receiving tremendous attention. The toxic HM's could also gradually accumulate in human body through food chain and cause damage to human health (Chen et al., 2009). In the Egyptian irrigation system, the main source of copper $(\mathrm{Cu})$ and lead $(\mathrm{Pb})$ are industrial wastes as well as algaecides (for $\mathrm{Cu}$ ), while that of cadmium $(\mathrm{Cd})$ is the phosphatic fertilizers used in crop farms (Mason, 2002). Plants grown on sewer water irrigation such as acacia, salix and common reed which used as fodder to dairy animals had higher concentration of heavy metals (Bansal, 2004). Rozso et al. (2003) detected the heavy metals of forages and roughages produced in agricultural regions and the neighboring cities, industrial plants and busy highways. The removal of heavy metal ions using low-cost abundantly available adsorbents: agricultural wastes by-products were used and investigated (Hashem et al., 2007; Buasri et al., 2012 and Zwain et al., 2014). Chitosan is a cationic carbohydrate polymer derived from chitin. It's a natural nontoxic biopolymer produced by the deacetylation of chitin, a major component of the shells of crustaceans such as crab, shrimp, and crawfish (Wenshui et al., 2010). Furthermore, chitosan is largely used as a non-toxic flocculent in the treatment of organic polluted wastewater and as a chelating agent for the removal of toxic heavy and reactive metals from industrial wastewater (Jeon et al., 2001). Its derivative, chitosan (poly [b-(1-4)-2-amino-2-deoxy- Dglucopyranose]), a polymer of D-glucosamine, has reactive amino groups which are responsible for complex formation between metal ions and the polymer chain. Jayathilakan et al. (2012) cited that one of the important applications of chitosan is the removal of proteinaceous matter in the food industry; its positive charge can be used for coagulation and recovery of proteinaceous materials present in such food processing operations. Pectins can be obtained from sugar-beet pulp (SBP), a residue of the sugar processing industry. Compared to other pectins obtained from other sources, like citrus, apple and sunflower pectins, SBP pectins have the advantage that the raw material is already dried and does not depend on stationality. SBP is used as animal feed at very low prices and is readily available; it has high pectin content (15-30\%) (Mata et al., 2009). Most of the pectins present in the SBP are high in methoxyl group and have more than $50 \%$ of methoxylated residues. Therefore, the main functional groups of pectin are: hydroxyl, carboxyl, amide and methoxyl. These functional groups have been traditionally associated to heavy metal binding, especially carboxyl groups with a great bio sorption and heavy metal removal potential (Mata et al., 2009). Many by-products rich in pectin such as apple waste, SBP and citrus peels have been studied for their metal binding capability (bio sorption) (Schiewer and Patil, 2008). Vitamin C has been reported to act as a chelating agent of $\mathrm{Pb}$, with a similar potency to that of EDTA (Goyer and Cherian, 1979). El-Sokkary and Awadalla (2011) cited that vitamin C; in large doses could acts as a chelating agent. Also, it helps to protect animals from HM"s. Also, can be used to protect animal from the environmental pollution effect and is a free radical fighter as well. The objective of the present study were to determine the concentration of heavy metals ions in soils and water under effluents irrigation and fodder which irrigated by wasted water and to evaluate the effect of some supplements such as chitosan, pectin or vitamin $\mathrm{C}$ as tools for removing of heavy metals and study their effects on the digestibility coefficient, rumen fermentation, blood parameters and goats performance. Also, to evaluate the toxic level of metal ions in the milk of animal by effluents irrigated fodder.

\section{MATERIALS AND METHODS}

\section{Study area:}

The study area was located in New Borg El-Arab city, $60 \mathrm{~km}$ west of Alexandria, Egypt. The soil obtained from the field was calcareous, irrigated by wastewater. It was neighboring from industrialized region. Alexandria City has been generating a huge amount of wastewater from domestic, agricultural and industrial sectors (Abd El-Hady, 2007).

\section{Plant sampling and analysis:}

The edible parts of acacia (acacia saligna) were harvested from March to May 2012. The plant material samples were collected in brown paper bags and taken to the laboratory for oven dried at 60$70^{\circ} \mathrm{C}$. Then they were grounded and passed through a standard sieve ready for extraction. Ash samples 


\section{Hassan et al.}

were quantitatively transferred into $10 \mathrm{ml}$ concentrated nitric acid (Jones and Case, 1990). Cadmium (Cd), chromium $(\mathrm{Cr})$, copper $(\mathrm{Cu})$, nickel $(\mathrm{Ni})$, lead $(\mathrm{Pb})$ and zinc $(\mathrm{Zn})$ concentrations in the plant samples were determined by the inductively coupled plasma optical emission spectrometer (model Perkin Elmer Optima 2000 DV), using the Atomic Adsorption Spectrometer.

\section{Soil and irrigation canal water sampling and characterizations:}

Wastewater used for irrigation and reference soils were collected at the same time of harvesting acacia. The soil samples were collected from 0-30, 30-60 and 60-90 cm deep at the root zone and it mixed together to form a composite sample. Soil was air-dried and sieved through a $<2 \mathrm{~mm}$ mesh, and then sealed in Kraft paper envelopes until analysis. Sub-samples were used to measure the physico-chemical properties according to standard procedures. For the heavy metal concentrations, soil was extracted by aqua regia at $160^{\circ} \mathrm{C}$ and then metal concentrations in the digests were determined by the inductively coupled plasma optical emission spectrometer (model Perkin Elmer Optima 2000 DV), using the Atomic Adsorption Spectrometer. Three wastewater samples were collected from canals water .Water samples were taken in labeled plastic bottles and transported to the laboratory of Soil and Environmental Sciences to be determine electrical conductivity (EC), $\mathrm{pH}$ and heavy metals $(\mathrm{Cd}, \mathrm{Cr}, \mathrm{Cu}, \mathrm{Ni}, \mathrm{Pb}$, and $\mathrm{Zn}$ ) were measured according to Walsh (1971).

\section{Digestibility and nitrogen balance trials:}

Four digestibility and nitrogen balance trials were carried out using twelve zaraibi bucks averaging $50.2 \mathrm{~kg}$ weight (three bucks for each diet). Each trial lasted for 42 days; the first 35 days as a preliminary period, followed by 7days for feces and urine collection. Animals were offered acacia ad libitum twice a day at 8.00 and 16.00 plus restricted amount of CFM to cover 50\% of protein requirements according to NRC (2007). Water was offered freely. Experimental diets were; concentrate feed mixture (CFM) plus acacia irrigated with wastewater, as control $\left(\mathrm{D}_{1}\right) ; \mathrm{D}_{1}$ plus $5 \mathrm{gm} / \mathrm{head} / \mathrm{d}$ chitosan to be added to CFM $\left(\mathrm{D}_{2}\right)$; $\mathrm{D}_{1}$ plus $20 \mathrm{gm} /$ head /d purified pectin to be added to $\mathrm{CFM}\left(\mathrm{D}_{3}\right)$ and $\mathrm{D}_{1}$ plus $500 \mathrm{mg}$ vitamin $\mathrm{C}$ to be added to CFM $\left(D_{4}\right)$. Sub samples $(20 \%)$ of feces and urine were taken once daily and frozen until analyses. Chemical analyses of diets, faeces and urine were undertaken followed the methods of AOAC (2005). Cell wall was analyzed for neutral detergent fiber (NDF), acid detergent fiber (ADF) and acid detergent lignin (ADL) using Tecator Fibretic system. Hemicellulose and cellulose were determined by difference according to Van Soest et al. (1991). Values of the total digestible nutrients (TDN) were calculated according to the classic formula of Maynard et al. (1978) on dry matter basis (DM). Concentrate feed mixture (CFM) consists of 35\% yellow corn, $18 \%$ soybean meal, $28 \%$ wheat bran, $10 \%$ barly grain, $5 \%$ molasses, $2 \%$ limestone, $1 \%$ salt, $0.5 \%$ mineral mixtures, $0.5 \%$ vitamin mixtures was used in the feeding trials. Chitosan (poly D-glucosamine)-deacetylated chitin, Sigma-Aldrich Co., St. Louis, MO, USA). Pectin (Poly- galacturonic acid methyl ester $\geq 74.0 \%$ (dried basis), Sigma-Aldrich Co., St. Louis, MO, USA). Table (1) illustrated the chemical analyses and fiber fractions of CFM and fresh acacia (FA) which irrigated by wasted water.

\section{Ruminal liquor parameters:}

Samples of rumen liquor were taken at $0,1,3$ and $6 \mathrm{~h}$ post feeding from three fistulated adult Zaraibi does with approximately $32.5 \pm 0.5 \mathrm{~kg}$ BW for each treatment consequently. Samples were analyzed immediately for $\mathrm{pH}$ using Orion 680 digital $\mathrm{pH}$ meter.

The rumen fluid samples were preserved for ammonia nitrogen $\left(\mathrm{NH}_{3}-\mathrm{N}\right)$ determination by adding concentrated $\mathrm{H}_{2} \mathrm{SO}_{4}$ ( 3 drop per $5 \mathrm{ml}$ ). The concentration of $\mathrm{NH}_{3}-\mathrm{N}$ was determined by using magnesium oxide $(\mathrm{MgO})$ as described by the AL-Rabbat et al. (1971). Concentration of total volatile fatty acid (VFA's) was estimated by using steam methods (Warner, 1964). Total bacteria count was carried out according to Difco (1984). The microbial nitrogen synthesis in the rumen of goats was determined according to the method of Makkar et al. (1982) using tungstic acid.

\section{Lactation trial:}

Twenty lactating Zaraibi does in the $2^{\text {nd }}$ and $3^{\text {rd }}$ season of lactation, aging 2-4 years with $34.40 \mathrm{Kg}$ in average were randomly divided into four similar groups (five goats each) to carry on the lactation trial for a period of 60 days. Goats were randomly assigned to the four experimental diets using a randomized complete block design (Steel and Torrie, 1980). Before the start of the experiment all does were kept for 7 days as an adaptation period during which all animals were treated with Ivomec ${ }^{\circledR}$ against external and internal parasites. Goats were fed on restricted amount of CFM to cover $50 \%$ of protein requirements according to NRC (2007), while acacia forage was fed ad libitum and the actual amount of acacia 


\section{Hassan et al.}

consumed was daily recorded. The CFM was fed twice a day at 8.00 and 16.00 and animals were weighed biweekly for two successive days. Drinking water was available all times. Milk yield was individually recorded on two successive days, and milk samples were collected twice daily for 4 times in the 60 days through the collection period from all goats according to Galatov (1994). Milk samples were chemically analyzed for total solid (TS), protein, fat and ash according to AOAC (2005), while lactose was calculated by difference. Kids were kept in a separate enclosure and allowed to suckle their dams for a short period in the morning and in the evening just at the time of milking. Samples were collected immediately after milking from goats, and then wet ashing procedure was chosen for blood and milk. The method of Ataro et al. (2008) was adopted for digestion of liquid samples (blood and milk) and heavy metals ( $\mathrm{Cd}, \mathrm{Cr}, \mathrm{Cu}$, $\mathrm{Ni}, \mathrm{Pb}$ and $\mathrm{Zn}$ ) concentrations in the prepared samples were determined by the inductively coupled plasma optical emission spectrometer (model Perkin Elmer Optima 2000 DV), using the Atomic Adsorption Spectrometer.

Table (1). Proximate chemical analyses and fiber fractions of the experimental CFM and fresh acacia (on dry matter basis, \%).

\begin{tabular}{lcc}
\hline Item & CFM & Fresh acacia \\
\hline Chemical analysis: & & \\
OM & 92.08 & 88.64 \\
CP & 15.83 & 14.62 \\
CF & 5.74 & 25.83 \\
EE & 3.13 & 2.14 \\
Ash & 7.92 & 11.36 \\
NFE & 67.38 & 46.05 \\
Fiber fractions: & & \\
NDF & 24.92 & 51.54 \\
ADF & 12.33 & 34.72 \\
ADL & 9.56 & 12.92 \\
Hemicellulose & 12.59 & 16.82 \\
Cellulose & 2.77 & 21.80 \\
\hline
\end{tabular}

\section{Sampling and analysis of blood serum:}

Blood samples were collected at the end of the experimental period from all goats. Blood samples were obtained from the jugular vein of the goats in the morning before access to feed and water. Serum was obtained by centrifugation of blood and stored at $-20{ }^{\circ} \mathrm{C}$ until used for analysis, while whole blood samples were used for determined heavy metals concentrations. Glucose concentration was determined by the method of Trinder (1969). Serum cholesterol was determined using the colorimetric method of Stein (1986). Serum total protein (TP) was measured as described by the Biuret method according to Henry et al. (1974). Albumin (A) concentration was determined according to Doumas et al. (1971). Kidney function was evaluated by measuring blood urea using the colorimetric methods of Henry and Todd (1974). Liver functions were assessed by measuring the activities of aspartate aminotransferase (AST) and alanine aminotransferase (ALT) by the method of Reitman and Frankel (1957).

\section{Statistical Analysis:}

Collected data were statistically analyzed using the method of least squares analysis of variance using General Linear Models (GLM) procedure (SAS, 2004). The model used was as follow:

$\mathrm{Y}_{\mathrm{ij}}=\mu+\mathrm{T}_{\mathrm{i}}+\mathrm{e}_{\mathrm{ij}}$

Where: $Y_{i j}=$ an observation taken on the $j^{\text {th }}$ individual, $\mu=$ overall mean, $T_{i}=$ a fixed effect of the $i^{\text {th }}$ treatment ( $\mathrm{i}=1$ to 4$), \mathrm{e}_{\mathrm{ij}}=\mathrm{A}$ random error assumed to be normally distributed with mean $=0$ and variance $=\sigma^{2}$. Significant differences among means were separated using LSD test according to Duncan (1955). 


\section{RESULTS AND DISCUSSION}

\section{Physico-chemical properties of irrigation wastewater, soil and plant:}

Data in Table (2) showed that $\mathrm{pH}$ of acacia plant in this study was markedly lower than that of irrigation wastewater or soil in new Borg Al-Arab site. All heavy metals content in acacia were considerably higher than that in irrigation wastewater or soil. When wastewater, soil and acacia samples were analyzed for heavy metals $(\mathrm{Cd}, \mathrm{Cr}, \mathrm{Cu}, \mathrm{Ni}, \mathrm{Pb}$ and $\mathrm{Zn}$ ) it was found that the concentrations of HM's were beyond the maximum permissible limits declared by (WHO, 2006). Analysis of chemical parameters of water and soil concluded that $\mathrm{pH}$ and electrical conductivity were within the normal range set by (WHO, 2006). The nickel, cadmium, chromium, and lead contents in wastewater were much higher than those in irrigation waters, the levels are higher than the acceptable levels reported by FAO guidelines (FAO, 2007) for crop production. The reason for this extremity in values is might be due to the addition of civic wastes and industrial effluents as the sewage of the city is directly discharged into the agriculture wastewater canal. This is in agreement with the studies (Hassan et al., 2012) who reported that the level of heavy metals increasing in the rivers due to discharge of industrial effluents and civic pollution of various kinds. With increasing depth of soil sample concentrations of heavy metals were decreased. The $\mathrm{Pb}$ level in the plants was higher than the recommended limits of $0.5-10 \mathrm{mg} / \mathrm{kg}$ (FAO, 2007). Contamination with $\mathrm{Pb}$ in forages and roughages produced from industrial areas and nearby busy roads was higher than that in plants from agricultural areas (Rozso et al., 2003). In India plants grown on sewer irrigation water had higher concentration of $\mathrm{Zn}, \mathrm{Cu}, \mathrm{Cd}, \mathrm{Cr}$ and $\mathrm{Ni}$ as compared to fields irrigated by underground water (Bansal, 2004). Lawes (1993) had showed that the $\mathrm{pH}$ of the irrigated soil below a depth of $15 \mathrm{~cm}$ could increase by about 0.5 units.

Table (2). Average pH, EC and concentrations of heavy metals of irrigation wastewater, soil and acacia plant.

\begin{tabular}{cccccc}
\hline Properties & $\begin{array}{c}\text { Contaminated } \\
\text { Wastewater } \\
\left(\mathrm{mgL}^{-1}\right)\end{array}$ & $0-30 \mathrm{~cm}$ & $\begin{array}{c}\text { Contaminated soils } \\
\left(\mathrm{mg} \mathrm{kg-}^{1}\right)\end{array}$ & $\begin{array}{c}\text { Contaminated } \\
\text { Plant }\end{array}$ \\
\hline $\mathrm{pH}$ & 8.3 & 8.2 & 8.3 & 8.3 & $60-90 \mathrm{~cm}$ \\
E.C.dSm & 1.1 & 0.64 & 0.81 & 1.62 & 7.11 \\
$\mathrm{Cd}$ & 1.02 & 0.49 & 0.45 & 0.43 & - \\
$\mathrm{Cr}$ & 0.08 & 1.35 & 1.27 & 1.25 & 2.07 \\
$\mathrm{Cu}$ & 0.97 & 2.77 & 2.13 & 2.08 & 4.81 \\
$\mathrm{Ni}$ & 0.58 & 0.15 & 0.12 & 0.09 & 2.39 \\
$\mathrm{~Pb}$ & 0.09 & 2.09 & 1.16 & 1.12 & 11.14 \\
$\mathrm{Zn}$ & 0.35 & 2.48 & 1.58 & 1.55 & 12.74 \\
\hline
\end{tabular}

\section{Dry matter intake, digestibility, nutritive values and nitrogen utilization:}

Dry matter intake $(\mathrm{DMI})$ was significantly higher $(\mathrm{P}<0.01)$ for bucks fed diet supplemented with pectin $\left(D_{3}\right)$ or vitamin $C\left(D_{4}\right)$ followed by chitosan $\left(D_{2}\right)$ supplement compared with the control one (Table $3)$. The digestibility coefficients, nutritive values and nitrogen utilization were followed the same trend. However, high $(\mathrm{P}<0.01)$ digestibility coefficients was observed for pectin or vitamin $\mathrm{C}$ supplement diets, the less was found for $\mathrm{D}_{1}$ and $\mathrm{D}_{2}$. These were reflected on TDN, DCP and N-utilization values. In a previous study, chitosan formed a highly viscous solution in the gastrointestinal tract of animals because of its melting properties in weak acid (Sugano et al., 1988), and caused a full stomach in animals by expanding the duodenum region (Razdan and Petterson, 1994). A reduction of in vitro digestibility for maize silage diet and a different forage-concentrate diet with chitosan $(325,750$, and $1500 \mathrm{mg} / \mathrm{L} \mathrm{of}$ culture fluid) has also been previously observed (Goiri et al., 2009a and Goiri et al., 2009c). A slight decrease in the digestibility in sheep given chitosan $(136 \mathrm{mg} / \mathrm{kg}$ of BW) daily via rumen fistula has also been reported (Goiri et al., 2010). On the other hand, Han et al. (2007) found that the best nutrient digestibility and higher crude fat $(\mathrm{EE})$ digestibility $(\mathrm{p}<0.005)$ when pigs fed diet supplemented with $(0.4 \%$ Chitosan for starter $(6-13 \mathrm{~kg})$ and $0.3 \%$ for grower $(13-30 \mathrm{~kg})$ stages compared with the control. El-Badawi and El-Kady (2006) believed that the high water holding capacity of dry sugar beet pulp due to 


\section{Hassan et al.}

the existence of pectin substances, methyl and carboxyl groups in its molecular structure may be the reason of its better digestion. In the same time, inclusion of pectin source in feeding of ruminants delays rate of passage outside the rumen (El-Badawi et al., 2003) and increased Lactobacilli and Streptococci and enzymatic yield of polygalacturonase and pectin esterase (El-Badawi et al., 2001). However, Omer et al. (2013) found that inclusion of sugar beet pulp to substitute yellow corn in sheep ration insignificantly $(\mathrm{P}>0.05)$ improved DM and OM digestibilties, while, it significantly $(\mathrm{P}<0.05)$ increased CF digestibilties, but, it significantly $(\mathrm{P}<0.05)$ decreased EE digestibility.

Data of nitrogen retained was positive for all experiment groups. N-retained as a percentage of Nintake was significantly higher $(\mathrm{P}<0.01)$ with pectin or vitamin $\mathrm{C}$ supplementation than the control and chitosan groups, while it insignificantly differ between chitosan group and control group. The same trend was observed for $\mathrm{N}$-utilization when it expressed as $\mathrm{N}$-retained/ $\mathrm{N}$-absorption (\%). These results were in agreement with those found by El-Badawi et al. (2003) and Mousa (2011). Generally, the superiority in nitrogen retention due to a specific ration is affected by several factors such as possible production of microbial protein synthesis, increasing presence of fermentable energy (Hagemeister et al., 1981), variability in nitrogen that might escape fermentation from the rumen, an increased utilization of ammonia in the rumen (Holzer et al., 1986) and the effect of free fats in protein synthesis (Sutton et al., 1983).

Table (3). Feed intake, digestibility coefficients, nutritive values and nitrogen utilization for bucks fed the experimental diets.

\begin{tabular}{|c|c|c|c|c|c|c|}
\hline \multirow{2}{*}{ Item } & \multicolumn{4}{|c|}{ Experimental diets } & \multirow[b]{2}{*}{ SEM } & \multirow[b]{2}{*}{ Sig } \\
\hline & $\mathrm{D}_{1}$ & $\mathrm{D}_{2}$ & $\mathrm{D}_{3}$ & $\mathrm{D}_{4}$ & & \\
\hline \multicolumn{7}{|l|}{ Feed intake $(\mathrm{g} / \mathrm{d} / \mathrm{h})$ : } \\
\hline CFM & 537 & 537 & 537 & 537 & - & - \\
\hline Acacia & $506^{\mathrm{c}}$ & $541^{\mathrm{b}}$ & $659^{a}$ & $626^{\mathrm{a}}$ & 10.65 & $* *$ \\
\hline TDMI & $1043^{\mathrm{c}}$ & $1078^{b}$ & $1196^{\mathrm{a}}$ & $1163^{\mathrm{a}}$ & 11.64 & $* *$ \\
\hline \multicolumn{7}{|c|}{ Digestibility coefficients (\%): } \\
\hline $\mathrm{DM}$ & $59.68^{c}$ & $61.97^{\mathrm{b}}$ & $66.40^{\mathrm{a}}$ & $65.93^{\mathrm{a}}$ & 0.58 & $* *$ \\
\hline OM & $61.02^{\mathrm{c}}$ & $63.13^{\mathrm{b}}$ & $67.37^{\mathrm{a}}$ & $66.40^{\mathrm{a}}$ & 0.44 & $* *$ \\
\hline $\mathrm{CP}$ & $56.40^{\mathrm{b}}$ & $56.88^{b}$ & $62.16^{\mathrm{a}}$ & $61.74^{\mathrm{a}}$ & 0.78 & $*$ \\
\hline $\mathrm{CF}$ & $52.13^{\mathrm{b}}$ & $51.97^{\mathrm{b}}$ & $59.07^{\mathrm{a}}$ & $57.22^{\mathrm{a}}$ & 2.41 & * \\
\hline $\mathrm{EE}$ & $67.43^{\mathrm{b}}$ & $70.10^{\mathrm{a}}$ & $72.44^{\mathrm{a}}$ & $72.29^{\mathrm{a}}$ & 2.76 & $*$ \\
\hline NFE & $65.50^{\mathrm{b}}$ & $68.69^{\mathrm{a}}$ & $71.67^{\mathrm{a}}$ & $70.19^{\mathrm{a}}$ & 1.21 & $*$ \\
\hline \multicolumn{7}{|l|}{ Nutritive value (\%) } \\
\hline TDN & $58.01^{\mathrm{c}}$ & $59.97^{\mathrm{b}}$ & $63.44^{\mathrm{a}}$ & $62.30^{\mathrm{ab}}$ & 0.45 & $* *$ \\
\hline $\mathrm{DCP}$ & $8.55^{\mathrm{b}}$ & $8.66^{\mathrm{b}}$ & $9.43^{\mathrm{a}}$ & $9.37^{\mathrm{a}}$ & 0.26 & $*$ \\
\hline \multicolumn{7}{|c|}{ Nitrogen utilization $(\mathrm{g} / \mathrm{h} / \mathrm{d})$ : } \\
\hline $\mathrm{N}$-intake $(\mathrm{g} / \mathrm{d})$ & $25.45^{\mathrm{c}}$ & $26.25^{\mathrm{b}}$ & $29.02^{\mathrm{a}}$ & $28.23^{\mathrm{a}}$ & 0.42 & $* *$ \\
\hline N-retained (g/d) & $4.97^{\mathrm{b}}$ & $5.21^{\mathrm{b}}$ & $9.21^{\mathrm{a}}$ & $8.18^{\mathrm{a}}$ & 0.29 & $* *$ \\
\hline $\mathrm{N}$-absorbed $(\mathrm{g} / \mathrm{d})$ & $14.28^{\mathrm{b}}$ & $14.93^{\mathrm{b}}$ & $18.04^{\mathrm{a}}$ & $17.43^{\mathrm{a}}$ & 0.79 & $* *$ \\
\hline $\begin{array}{l}\mathrm{N} \text { - retained as } \% \text { of } \mathrm{N} \text { - } \\
\text { intake }\end{array}$ & $19.56^{\mathrm{b}}$ & $19.86^{\mathrm{b}}$ & $31.74^{\mathrm{a}}$ & $28.98^{\mathrm{a}}$ & 1.21 & $* *$ \\
\hline $\begin{array}{l}\mathrm{N} \text { - retained as } \% \text { of } \mathrm{N}- \\
\text { absorbed }\end{array}$ & $34.83^{b}$ & $34.90^{\mathrm{b}}$ & $51.05^{\mathrm{a}}$ & $46.93^{\mathrm{a}}$ & 1.36 & $*$ \\
\hline
\end{tabular}

$* * P<0.01$ and $* P<0.05$

$a, b$ and $c:$ means in the same row with different superscripts are differ significantly $(P<0.05)$ or $(P<0.01)$.

$D_{l}$ : concentrate feed mixture (CFM) plus acacia, control.

$D_{2}$ : D 1 plus $5 \mathrm{gm} /$ head/d chitosan added to CFM.

$D_{3}: D_{1}$ plus $20 \mathrm{gm} / \mathrm{head} / \mathrm{d}$ pectin added to CFM.

D4: D1 plus $500 \mathrm{mg} / \mathrm{h} / \mathrm{d}$ vitamin $C$ added to $C F M$.

\section{Ruminal liquor parameters:}

Data of ruminal $\mathrm{pH}$ values did not significantly differ by supplementation materials (Table 4). The control one was showed the highest $(\mathrm{P}<0.01) \mathrm{NH}_{3}-\mathrm{N}$ value and the lowest $(\mathrm{P}<0.01)$ value of TVFA's concentrations than the supplementation diets. Goiri et al. (2008) found that chitosan treatments 


\section{Hassan et al.}

decreased $\mathrm{NH}_{3}-\mathrm{N}$ concentration in a dose-dependent manner compared with control. However, (Chalupa et al., 1980) observed that inclusion of chitosan could reduction in CP disappearance and amino acid degradation which associated with a reduction in $\mathrm{NH}_{3}$ production. So, in the light of the observed results, chitosans could be used as a means of increase dietary protein escape from ruminal degradation. The higher $(\mathrm{P}<0.01)$ VFA's concentrations obtained with pectin or vitamin $\mathrm{C}$ supplementation; could be reflected from their more digestibility coefficients, or may be related to the more utilization of dietary energy and positive fermentation in the rumen. These findings agreed with those found by Omer et al. (2013) who illustrated that inclusion of sugar beet pulp (SBP) as pectin-rich food in sheep ration significantly $(\mathrm{P}<0.05)$ decreased ammonia nitrogen concentration, while, it significantly $(\mathrm{P}<0.01)$ increased total volatile fatty acids concentration, however it had no significant effect on $\mathrm{pH}$ value compared to control ration. Also, Abedo (2006) noticed that ammonia nitrogen concentration was significantly $(\mathrm{P}<0.01)$ lower for animals fed rations contained 25 and 50\% SBP than the control group.

Table (4). Overall mean of rumen parameters of does fed the experimental diets.

\begin{tabular}{|c|c|c|c|c|c|c|}
\hline \multirow[t]{2}{*}{ Item } & \multicolumn{4}{|c|}{ Experimental diets } & \multirow[b]{2}{*}{ SEM } & \multirow[b]{2}{*}{ Sig } \\
\hline & $\mathrm{D}_{1}$ & $\mathrm{D}_{2}$ & $\mathrm{D}_{3}$ & $\mathrm{D}_{4}$ & & \\
\hline $\mathrm{Ph}$ & 6.26 & 6.23 & 6.20 & 6.33 & 0.15 & NS \\
\hline $\mathrm{NH}_{3}-\mathrm{N}(\mathrm{mg} / 100 \mathrm{mlR} . \mathrm{L})$ & $17.64^{\mathrm{a}}$ & $11.98^{\mathrm{b}}$ & $12.37^{\mathrm{b}}$ & $12.25^{\mathrm{b}}$ & 0.42 & $* *$ \\
\hline TVFA's (meq/100 mlR.L) & $8.42^{\mathrm{c}}$ & $11.32^{\mathrm{b}}$ & $12.65^{\mathrm{a}}$ & $12.04^{\mathrm{a}}$ & 0.19 & $* *$ \\
\hline Acetic acid, $\%$ & $55.56^{\mathrm{b}}$ & $55.59^{\mathrm{b}}$ & $59.97^{\mathrm{a}}$ & $58.52^{\mathrm{a}}$ & 0.36 & $*$ \\
\hline propionic acid, \% & $24.75^{\mathrm{b}}$ & $26.31^{\mathrm{a}}$ & $24.60^{\mathrm{b}}$ & $24.69^{b}$ & 0.41 & $*$ \\
\hline Butyric acid, \% & 12.59 & 12.18 & 12.22 & 12.15 & 0.75 & NS \\
\hline Acetic : propionic ratio & $2.24^{\mathrm{b}}$ & $2.11^{\mathrm{cb}}$ & $2.44^{\mathrm{a}}$ & $2.37^{\mathrm{a}}$ & 0.10 & $*$ \\
\hline Tata bacteria count,$\times 10^{7}$ & $6.38^{\mathrm{b}}$ & $6.66^{\mathrm{b}}$ & $9.19^{\mathrm{a}}$ & $9.06^{\mathrm{a}}$ & 0.12 & $*$ \\
\hline Microbial protein yield (mg/dl) & $152.70^{\mathrm{b}}$ & $161.28^{\mathrm{ab}}$ & $180.61^{\mathrm{a}}$ & $176.34^{\mathrm{a}}$ & 5.14 & $*$ \\
\hline
\end{tabular}

$* * P<0.01$, * $P<0.05$ and N.S = Not significant.

$a, b$ and $c: m e a n s$ in the same row with different superscripts are differ significantly $(P<0.05)$ or $(P<0.01)$.

Molar proportion of VFA's in rumen of does showed that acetate concentration was significant lower in control and chitosan groups than the other supplemented groups. The propionic acid concentration was significantly higher with chitosan group than that the control and other supplemented groups. Supplementation with chitosan increased propionate production without decreasing production of acetate, whereas it in agreement with the results of in vitro trials reported by Goiri et al. (2008). Also, Goiri et al. (2009b) cited that supplementation with chitosan increased propionate production without decreasing production of acetate. So, it was accepted that as propionate production could enhanced at the expenses of acetate, the metabolically useful energy recovered in fermentation end products is increased. Moreover, it was described that increased propionate could also lowered heat increment and stimulate body protein synthesis. Thus, it can be hypothesized that chitosan could used as ionophores to improve the efficiency of feed conversion into animal products through these mechanisms. Addition of chitosan exerted an effect on some fermentative processes in the rumen, which may improve in vitro energy efficiency. It was seen that pectin and vitamin $\mathrm{C}$ supplementation was lead to an increase in the numbers of ruminal bacteria and their activities (Table 4), which could increase forages digestibility and increase the flow rate of microbial protein as well and may alter the patterns of VFA's. Goiri et al. (2008) noticed through in vitro trials that in these incubations where microbial growth could have been limited by the addition of chitosan, low efficiency of microbial synthesis could be expected and consequently, increased VFA production in relation to the fermentable substrate. Sugar beet pulp as a pectin-rich food causes a lower production of propionic and lactic acid, and high potential rumen degradability and apparent digestibility. In the pectin group it had more activity of rumen cellulolytic bacteria thus depressing rumen cell wall fermentation and roughage intake as well (Broderick et al., 2002). Microbial protein yield was significantly $(\mathrm{P}<0.05)$ increased for supplemented groups than control group. There was a good efficiency in ruminal protein synthesis when a no protein nitrogen source was in feeds containing rapidly fermentable carbohydrates (Lanza et al., 2001). Therefore, the use of SBP may have increased ruminal protein synthesis. This may be a good reason for protein saving and environmental protection with less ruminant manure (nitrogen) pollution (Olfaz et al., 2005). The reduction of ammonia nitrogen in the rumen liquor appears to be a result of increased incorporation of ammonia nitrogen into microbial protein and it was considered as a direct result to stimulated microbial activity. While, increasing TVFA's may be 
related to the more utilization of dietary energy and positive fermentation in the rumen. However, addition of more fermentable carbohydrate to ruminant rations could cause a decrease in rumen ammonia (Tagari et al., 1964) probably due to a greater uptake of ammonia by rumen microorganisms in support of enhanced microbial growth.

\section{Milk yield and milk composition:}

In general goats fed diet supplemented with pectin or vitamin $\mathrm{C}$ had higher $(\mathrm{P}<0.01)$ milk yield and 4 $\%$ FCM yield compared with those of other groups (Table 5). While, those fed diet supplemented with chitosan had significantly higher values than control group that free from any supplement. The decrease of milk yield in control group could due to the decrease in DMI, digestibility coefficients and TVFA's production. All milk components were increased $(\mathrm{P}<0.05)$ with supplemented groups compared with control group except for ash. Farid and Baloch (2012) illustrated that the concentration of trace elements in diet affects milk quality because the nutrients are removed from the blood by mammary glands, converted in to milk and secreted into the udder. It's well known that nutrients for milk production were come from the feed, either directly or indirectly via body reserves of nutrients. Sorathiya et al. (2015) reported that partial replacement of green fodder with sugar beet tubers numerically improved dry matter intake, milk yield, $4 \%$ fat corrected milk and milk composition parameters such as fat, solid non-fat, protein and lactose. Cows fed diet consuming pectin-rich feeds had increasing milk fat concentration (Mansfield et al., 1994). Goiri et al. (2010) showed that chitosan was very effective source in inhibiting biohydrogenation in vitro by increasing C18:1 and conjugated linoleic acid (CLA) proportions and lowering the proportion of saturated fatty acids in the rumen in order to enhance the final CLA level in milk and meat products.

Table (5). Milk yields and milk composition for lactating goats fed the experimental diets.

\begin{tabular}{|c|c|c|c|c|c|c|}
\hline \multirow{2}{*}{ Item } & \multicolumn{4}{|c|}{ Experimental diets } & \multirow[b]{2}{*}{ SEM } & \multirow[b]{2}{*}{ Sig. } \\
\hline & $\mathrm{D}_{1}$ & $\mathrm{D}_{2}$ & $\mathrm{D}_{3}$ & $\mathrm{D}_{4}$ & & \\
\hline \multicolumn{7}{|c|}{ Production (kg/day): } \\
\hline Milk yields & $0.725^{\mathrm{c}}$ & $0.815^{b}$ & $0.995^{\mathrm{a}}$ & $0.970^{\mathrm{a}}$ & 0.19 & $* *$ \\
\hline $4 \% \mathrm{FCM}$ & $0.605^{c}$ & $0.701^{b}$ & $0.908^{a}$ & $0.868^{a}$ & 0.18 & $* *$ \\
\hline Milk fat & $0.021^{\mathrm{c}}$ & $0.025^{b}$ & $0.034^{\mathrm{a}}$ & $0.032^{\mathrm{a}}$ & 0.02 & $* *$ \\
\hline Milk protein & $0.021^{\mathrm{c}}$ & $0.025^{b}$ & $0.033^{\mathrm{a}}$ & $0.031^{\mathrm{a}}$ & 0.02 & $* *$ \\
\hline \multicolumn{7}{|c|}{ Milk composition (\%): } \\
\hline Total solids & $11.32^{\mathrm{c}}$ & $11.81^{b}$ & $12.38^{\mathrm{a}}$ & $12.25^{\mathrm{a}}$ & 0.22 & $* *$ \\
\hline Solids not fat & $8.34^{\mathrm{b}}$ & $8.78^{a b}$ & $8.96^{\mathrm{a}}$ & $8.90^{\mathrm{a}}$ & 0.18 & $*$ \\
\hline Fat & $2.98^{b}$ & $3.03^{\mathrm{b}}$ & $3.42^{\mathrm{a}}$ & $3.35^{\mathrm{a}}$ & 0.16 & $*$ \\
\hline Protein & $2.97^{\mathrm{b}}$ & $3.01^{\mathrm{b}}$ & $3.29^{\mathrm{a}}$ & $3.23^{\mathrm{a}}$ & 0.07 & $*$ \\
\hline Lactose & $4.40^{\mathrm{b}}$ & $5.02^{\mathrm{a}}$ & $4.94^{\mathrm{a}}$ & $4.91^{\mathrm{a}}$ & 0.26 & $*$ \\
\hline Ash & $0.97^{\mathrm{a}}$ & $0.75^{\mathrm{b}}$ & $0.73^{\mathrm{b}}$ & $0.76^{\mathrm{b}}$ & 0.09 & $*$ \\
\hline
\end{tabular}

** $P<0.01$ and $* P<0.05$.

$a, b$ and $c:$ means in the same row with different superscripts are differ significantly $(P<0.05)$ or $(P<0.01)$.

\section{Feed conversion:}

Feed conversion of chitosan, pectin and vitamin C supplementation to dairy goats diets are presented in Table 6. The results revealed that $\mathrm{D}_{3}$ was more efficient than other diets, while the least efficiency one was found with $\mathrm{D}_{1}$. Improved feed conversion by supplementation could be due to improved feed digestibility and metabolism; this is in agreement with those obtained by Shi et al. (2005) who illustrated that increasing chitosan inclusion gave a nonlinear increase $(\mathrm{P}<0.001)$ in feed conversion efficiency. Omer et al. (2013) reported that inclusion of SBP as pectin-rich feeds in sheep ration was significantly improved $(\mathrm{P}<0.05)$ feed conversion ratio ( $\mathrm{kg}$ intake of $\mathrm{DM}$, TDN and DCP/ $\mathrm{kg}$ gain).

\section{Blood biochemical and serum constituents:}

Values of some blood constituents measured in the blood of goats fed the different diets are presented in Table (7). Serum glucose, cholesterol, urea, AST and ALT concentrations were significantly $(\mathrm{P}<0.01)$ decreased with supplement of chitosan, pectin and vitamin $\mathrm{C}$ groups compared with those of control group. While, serum total protein; albumin and globulin were significantly $(\mathrm{P}<0.05)$ increased by the supplementation with pectin and vitamin $\mathrm{C}$, followed by chitosan compared with the control group. Blood 


\section{Hassan et al.}

glucose showed significant increase $(\mathrm{P}<0.01)$ due to heavy metal intoxication. This may be due to the vulnerable stress induced by these heavy metals resulted in hyperglycemia. Previous investigations

Table (6). Feed intake and feed conversion of daily milk production for does fed the experimental diets during lactation period.

\begin{tabular}{|c|c|c|c|c|c|c|}
\hline \multirow[t]{2}{*}{ Item } & \multicolumn{4}{|c|}{ Experimental diets } & \multirow[b]{2}{*}{ SEM } & \multirow[b]{2}{*}{ Sig. } \\
\hline & $\mathrm{D}_{1}$ & $\mathrm{D}_{2}$ & $\mathrm{D}_{3}$ & $\mathrm{D}_{4}$ & & \\
\hline \multicolumn{7}{|l|}{ Feed intake(kg/h/d): } \\
\hline DMI, $\mathrm{kg}$ & $1.072^{\mathrm{c}}$ & $1.091^{\mathrm{b}}$ & $1.205^{\mathrm{a}}$ & $1.189^{\mathrm{a}}$ & 15.85 & $* *$ \\
\hline TDNI, kg & $0.621^{\mathrm{c}}$ & $0.654^{\mathrm{b}}$ & $0.767^{\mathrm{a}}$ & $0.740^{\mathrm{a}}$ & 9.24 & $* *$ \\
\hline \multicolumn{7}{|c|}{ Feed conversion $(\mathrm{kg} / \mathrm{kg})$ : } \\
\hline DMI / FCM & $1.771^{\mathrm{a}}$ & $1.556^{\mathrm{b}}$ & $1.327^{\mathrm{d}}$ & $1.369^{\mathrm{c}}$ & 0.02 & $* *$ \\
\hline TDNI/ FCM & $1.026^{\mathrm{a}}$ & $0.932^{\mathrm{b}}$ & $0.844^{\mathrm{c}}$ & $0.852^{\mathrm{c}}$ & 0.02 & $* *$ \\
\hline
\end{tabular}

$a, b, c$ and $d$ : means in the same row with different superscripts are differ significantly $(P<0.01)$.

proved that, cadmium modulate the metabolism of carbohydrates, causing hyperglycemia by stimulating the glycogenolysis in some marine species (Zgurschi et al., 2013). The increase of glucose content in blood could be also because of intensive glycogenolysis and the synthesis of glucose from extra hepatic tissue proteins and amino acids (Almeida et al., 2001). Cholesterol is the most important sterol occurring in animal fats. It is equally distributed between plasma and red blood cells, but in adrenal cortex, it occurs in the esterified form. In the present investigation, blood cholesterol level was significantly $(p<0.01)$ increased with heavy metal exposed to the experimental group. The increased levels of cholesterol develop a weakness in the body of the goats which was observed in our study. In the present study, the increase in ALT and AST may be due to increase cellular basal metabolic rate, irritability and the destructive changes of liver and skeletal muscle cells (Ahmed and Shalaby, 1993). Similar results were achieved with goats dosed with lead by Abd El-Hameed et al. (2008) who revealed an increase of AST, GGT and AST. Also, in buffalo cows and bulls by El-Tohamy et al. (1997) and Zaki et al. (2001) who reported an increase of ALT and AST. Abou El-Naga et al. (2005) reported that the reduction in the availability of carbohydrates needed for energy was partially compensated by increasing the activity of glutamate dehydrogenase and amino oxidase; which are the enzymes of controlling the utilization of amino acids for energy. On the other hand, the responsible enzymes of protein-carbohydrate metabolism (aspartate and alanine transaminases) showed low levels in the tested groups than control group due to its sharing in transforming proteins to glycogen. Singh et al. (2011) reported that the decrease in protein values may be a result of damage of liver responsible for protein biosynthesis in the body as well as renal tissue damage. This study revealed a significant increase in urea indicating renal deficiency (Ghorbe et al., 2001). Similar results were detected after oral administration of lead in goat by Haneef et al. (1998).

Table (7). Blood serum parameters of lactating goats fed experimental diets.

\begin{tabular}{|c|c|c|c|c|c|c|}
\hline \multirow[t]{2}{*}{ Item } & \multicolumn{4}{|c|}{ Experimental diets } & \multirow[b]{2}{*}{ SEM } & \multirow[b]{2}{*}{ Sig. } \\
\hline & $\mathrm{D}_{1}$ & $\mathrm{D}_{2}$ & $\mathrm{D}_{3}$ & $\mathrm{D}_{4}$ & & \\
\hline Glucose, mg/dl & $80.87^{a}$ & $54.87^{c}$ & $67.87^{b}$ & $66.64^{b}$ & 2.34 & $* *$ \\
\hline Cholesterol, mg/dl & $98.87^{a}$ & $71.77^{\mathrm{c}}$ & $84.44^{b}$ & $73.33^{c}$ & 3.27 & $* *$ \\
\hline Total Protein, g/dl & $6.46^{c}$ & $6.96^{\mathrm{b}}$ & $7.69^{a}$ & $7.67^{\mathrm{a}}$ & 0.39 & $*$ \\
\hline Albumin, g/dl & $3.45^{\mathrm{b}}$ & $3.71^{\mathrm{ab}}$ & $3.98^{\mathrm{a}}$ & $3.96^{\mathrm{a}}$ & 0.43 & $*$ \\
\hline Globulin, g/dl & $3.01^{\mathrm{b}}$ & $3.25^{\mathrm{ab}}$ & $3.71^{\mathrm{a}}$ & $3.71^{\mathrm{a}}$ & 0.49 & $*$ \\
\hline Urea-N, mg/dl & $22.65^{a}$ & $11.77^{b}$ & $13.85^{b}$ & $13.43^{b}$ & 2.65 & $* *$ \\
\hline $\mathrm{AST}, \mathrm{u} / \mathrm{L}$ & $46.79^{a}$ & $37.03^{b}$ & $34.75^{c}$ & $34.94^{\mathrm{c}}$ & 0.85 & $* *$ \\
\hline $\mathrm{ALT}, \mathrm{u} / \mathrm{L}$ & $17.98^{\mathrm{a}}$ & $12.86^{\mathrm{b}}$ & $11.76^{\mathrm{c}}$ & $11.54^{\mathrm{c}}$ & 0.43 & $* *$ \\
\hline
\end{tabular}

$* * P<0.01$ and $* P<0.05$

$a, b$ and $c:$ means in the same row with different superscripts are differ significantly $(P<0.05)$ or $(P<0.01)$.

\section{Concentrations of heavy metals residues:}

The concentrations of HM's residues in blood, feces and milk for goats are presented in (Table 8). In the present study, removable materials of heavy metals to the rations was led to aggregates and binding 
with active groups in this materials and led to an increase expelled out of the body through the urine and feces, and it was clearly showed an increase in the concentration of heavy metals residues in the feces compared with the control group. But their residues in the blood and milk were low compared with control rations. Monkiewicz et al. (1994) and Kolacz et al. (1996) observed that an increases in the contents of $\mathrm{Zn}, \mathrm{Cu}, \mathrm{Cd}, \mathrm{Hg}$ and $\mathrm{Pb}$ in a region polluted by the copper industry. Py's (1999) reported that there were about 25 trace elements present in milk. Their concentration may vary and depend on local environment. He found some influence of impact of sulfur industry (Tarnobrzeg) on the content of $\mathrm{Cu}$, $\mathrm{Cr}, \mathrm{Fe}, \mathrm{Mn}, \mathrm{Pb}, \mathrm{Zn}$ in milk, but these concentrations were within the range of physiological values. Chitosan chelates five to six time greater amounts of metals than chitin due to the free amino groups exposed in chitosan during deacetylation of chitin (Singh and Nagendran, 2014). The positively charged $\mathrm{Cd}, \mathrm{Cr}, \mathrm{Ni}$ and $\mathrm{Pd}$ ions can bind by way of electrostatic interaction with the negatively charged surface of chitosan, mainly through carboxyl ligands. There was several factors affect on metal ion adsorption by chitosan (Guibal, 2004). Research had been done on the use of chitosan for the removal of some HM's ions from industrial wastewater (Nomanbhay and Palanisamy, 2005). The use of commercially available chitosan for potable water purification has been approved by the United States Environmental Protection Agency (US EPA) up to a maximum level of $10 \mathrm{mg} / \mathrm{L}$. (Knorr, 1984). Huang et al. (2009) reported that number of adsorption sites on chitosan increased with decreasing particle size. However, the citrus pectin has the ability to reduce total body burden of HM's. Once the total body burden of HM's is reduced, the chelation and detoxification process can be supported by utilizing additional compounds that can enhance the detoxification process, which help in excreting HM's from the organs and tissues into the blood stream. In addition in liver detoxification, provide the necessary thiol groups for detoxification, could help the elimination of toxic metals through the gut and urine, and support the body's detoxification and antioxidant pathways while providing stamina and support through the utilization of adaptogenic compounds (Hayashi et al., 2000). The extent of metal uptake by pectin is determined by its chemical structure and found to be increase with decrease in the degree of esterification (Silke and Ankit, 2009).

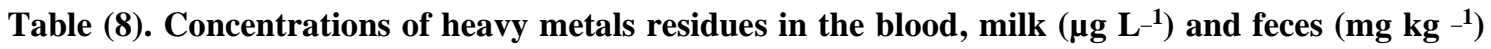
of goat samples fed the experimental diets.

\begin{tabular}{|c|c|c|c|c|c|c|c|}
\hline \multirow{2}{*}{ Item } & \multirow{2}{*}{ Heavy metals } & \multicolumn{4}{|c|}{ Experimental diets } & \multirow[b]{2}{*}{ SEM } & \multirow[b]{2}{*}{ Sig } \\
\hline & & $\mathrm{D}_{1}$ & $\mathrm{D}_{2}$ & $\mathrm{D}_{3}$ & $\mathrm{D}_{4}$ & & \\
\hline \multirow[t]{3}{*}{ Blood } & $\mathrm{Cd}\left(\mu \mathrm{g} \mathrm{L}-^{1}\right)$ & $1.15^{\mathrm{a}}$ & $1.09^{b}$ & $1.04^{\mathrm{c}}$ & $1.05^{\mathrm{c}}$ & 0.01 & $*$ \\
\hline & $\mathrm{Cu}\left(\mu \mathrm{g} \mathrm{L}-^{1}\right)$ & $7.24^{\mathrm{a}}$ & $5.18^{b}$ & $3.51^{\mathrm{c}}$ & $3.13^{\mathrm{c}}$ & 0.31 & $*$ \\
\hline & $\left.\mathrm{Ni} \mu \mathrm{g} \mathrm{L}^{-1}\right)$ & $4.11^{\mathrm{a}}$ & $3.08^{b}$ & $2.05^{\mathrm{c}}$ & $2.06^{\mathrm{c}}$ & 0.05 & $*$ \\
\hline \multirow[t]{4}{*}{ Feces } & $\mathrm{Cd}\left(\mathrm{mg} \mathrm{kg}^{1}\right)$ & $0.38^{\mathrm{c}}$ & $0.53^{b}$ & $0.68^{\mathrm{a}}$ & $0.63^{\mathrm{a}}$ & 0.03 & $* *$ \\
\hline & $\mathrm{Cr}\left(\mathrm{mg} \mathrm{kg}-^{1}\right)$ & $0.97^{\mathrm{c}}$ & $1.21^{\mathrm{b}}$ & $1.53^{\mathrm{a}}$ & $1.49^{\mathrm{a}}$ & 0.02 & $* *$ \\
\hline & $\mathrm{Cu}\left(\mathrm{mg} \mathrm{kg}^{1}\right)$ & $1.72^{\mathrm{c}}$ & $1.97^{\mathrm{b}}$ & $2.71^{\mathrm{a}}$ & $2.66^{\mathrm{a}}$ & 0.03 & $* *$ \\
\hline & $\mathrm{Ni}\left(\mathrm{mg} \mathrm{kg}^{1}\right)$ & $0.09^{b}$ & $0.13^{\mathrm{a}}$ & $0.14^{\mathrm{a}}$ & $0.13^{\mathrm{a}}$ & 0.01 & $*$ \\
\hline \multirow{5}{*}{ Milk } & $\mathrm{Cr}\left(\mu \mathrm{g} \mathrm{L}^{-1}\right)$ & $0.67^{\mathrm{a}}$ & $0.49^{b}$ & $0.20^{c}$ & $0.26^{c}$ & 0.06 & $*$ \\
\hline & $\mathrm{Cu}\left(\mu \mathrm{g} \mathrm{L}-^{1}\right)$ & $3.75^{\mathrm{a}}$ & $2.13^{b}$ & $1.06^{\mathrm{c}}$ & $1.09^{c}$ & 0.44 & $* *$ \\
\hline & $\mathrm{Ni}\left(\mu \mathrm{g} \mathrm{L}^{-1}\right)$ & $2.08^{\mathrm{a}}$ & $1.06^{\mathrm{b}}$ & $0.53^{c}$ & $0.60^{c}$ & 0.31 & $*$ \\
\hline & $\mathrm{Pb}\left(\mu \mathrm{g} \mathrm{L}-^{1}\right)$ & $1.12^{\mathrm{a}}$ & $0.88^{b}$ & $0.67^{\mathrm{c}}$ & $0.69^{c}$ & 0.12 & $* *$ \\
\hline & $\mathrm{Zn}\left(\mu \mathrm{g} \mathrm{L}^{-1}\right)$ & $19.19^{\mathrm{b}}$ & $15.02^{\mathrm{a}}$ & $11.81^{\mathrm{a}}$ & $12.03^{\mathrm{a}}$ & 1.22 & $*$ \\
\hline
\end{tabular}

$* * P<0.01$ and $* P<0.05$

$a, b$ and $c:$ means in the same row with different superscripts are differ significantly $(P<0.05)$ or $(P<0.01)$.

Reddad et al. (2002) illustrated that the waste pulp of sugar beet remaining from extraction of sugar, saponification and extraction of pectins has been as metal sorbent. It was confirmed that the native sugar beet pulp is dominated by negatively charged sites that are largey carboxylate groups with some weaker acidic groups. Mata et al. (2009) cited that most of the pectins present in the sugar-beet pulp are high methoxyl and have more than $50 \%$ of methoxylated residues. Different types of pectin demethylation methods can be used: acid, alkali, ammonia and enzyme treatments. Harel et al. (1998) used a sugar-beet 


\section{Hassan et al.}

pectin demethylation method using ammonia that yielded gels with enough mechanical strength and insolubility, suitable for biosorption applications. Refer to ascorbic acid can acts directly to neutralize superoxide radicals $\left(\mathrm{O}_{2} \bullet-\right)$, singlet oxygen $\left({ }^{1} \mathrm{O}_{2}\right)$ or hydroxyl radical $(\bullet \mathrm{OH})$ simply by acting as a secondary antioxidant during the reductive recycling of the oxidized form of $\alpha$-tocopherol (Khan et al., 2011).

\section{CONCLUSION}

It could be concluded that in order to improve nutrients digestibility, nitrogen utilization, milk production and high milk fat content of goats, supplementation their rations with chitosan or pectin or vitamin $\mathrm{C}$ could be recommended, however pectin or vitamin $\mathrm{C}$ will came in the first priority, while chitosan could came in the least priority. Not only that it could help in better functions of liver and kidney, meantime, it helps in removable of heavy metals as well. However, more studies are needed to complete the effect of chitosan; pectin and vitamin $\mathrm{C}$ in removing heavy metals to improve environmental pollution by toxic metals.

\section{REFERENCES}

Abd El-Hady, B.A. (2007). Compare the effect of polluted and River Nile irrigation water on contents of heavy metals of some soils and plants. Res. J. Agri. and Biol. Sci., 3(4): 287-294.

Abd El-Hameed, A.R.; S.I. Shalaby; A.H. Mohamed and H.A. Sabra (2008). Effect of oral administration of lead acetate on some biochemical and hormonal parameters during pregnancy in baladi goats. Global Veterinaria, 2 (6): 301-307.

Abdel-Sabour, M.F.; H.I. Abdel-Shafy and A.R. Mohamed (2005). Plant yield production and heavy metals accumulation as affected by sewage sludge application on desert soil. Sustainable Water Management, 1: 27-31.

Abdel-Shafy, H.I. and R.O. Aly (2002). Water issue in Egypt resources, pollution and protection endeavors. J. Cent. Euro. Occu. and Envi. Medi., 8 (1): 3-21.

Abedo, A.A. (2006). A study on the use of sugar beet pulp in the feed mixtures for ruminants. Ph.D Thesis. Agric. Sc., (Animal Nutrition), Department of Animal Production, Faculty of Agriculture, Ain Shams University, Egypt.

Abou EL-Naga, E.H.; K.M. EL-Moselhy and M.A. Hamed (2005). Toxicity of cadmium and copper and their effect on some biochemical parameters of marine fish MUGIL SEHELI. Egyp. J. of Aqua. Res., 31(2): 60-71.

Ahmed, W.M. and S.I. Shalaby (1993). Some enzymatic activity in sera and uterine homogenates in buffalo and cows during some reproductive phases and disorders. Indi. J. Anim. Sci., 63: 1248-1253.

Almeida, J.A.; E.L. Novelli; D.M. Silva and R. Alves-Junior (2001). Environmental cadmium exposure and metabolic responses of the Nile tilapia Oreochromis niloticus. Environ. Pollut, 114: 169-175.

Al-Rabbat, M.F.; R.L. Baldwin and W.C. Weir (1971). In vitro nitrogen-treacer technique for some kinetic measures of rumen ammonia. J. Dairy Sci., 54:150.

AOAC (2005), Official methods of analysis 18thed, Association of official analytical chemists, Washington, DC, U.S.A.

Ataro, A.; R.I. McCrindle; B.M. Botha; C.M. McCrindle and P.P. Ndibewu (2008). Quantification of trace elements in raw cow's milk by inductively coupled plasma mass spectrometry (ICP-MS). Food Chemistry, 111, 243-248.

Bansal, O.P. (2004). Uptake of heavy metals by crop plant. Poll. Res., 23: 501-506.

Broderick, G.A.; D.R. Mertens and R. Simons (2002). Efficacy of carbohydrate sources for milk production by cows fed diets based on alfalfa silage. In: J. Dairy Sci., 85: 1767-1776. 


\section{Hassan et al.}

Buasri, A.; N. Chaiyut; K. Tapang; S. Jaroensin and S. Panphrom (2012). Removal of $\mathrm{Cu}^{2+}$ from Aqueous Solution by Biosorption on Rice Straw - an Agricultural Waste Biomass. Inter. J. Envi. Sci., 3(1): 160-166.

Chalupa,W.; W. Corbett and J.R. Brethour (1980). Effects of monensin and amichloral on rumen fermentation. J. Anim. Sci., 51: 170-179.

Chen, Z.; Y. Zhao; Q. Li; J. Qiao; Q. Tian and X. Liu (2009). Heavy metal contents and chemical speciations in sewage-irrigated soils from the eastern suburb of Beijing, China. J. Food, Agri. and Envi., 7: 690-695.

Difco, M. (1984). Dehydrated culture media and reagents for microbiology $\left(10^{\text {th }} \mathrm{ed}\right)$., Difco laboratories, Michigan.

Doumas, B.T.; W.A. Watson and H.G. Biggs (1971). Albumin standards and the measurements of serum albumin with bromocresol green. Clin. Chem. Acta., 31: 87-96.

Duffus, J.H. (2002). "Heavy metal” - a meaningless term? Pure Appl Chem., 74:793-807.

Duncan, D.B. (1955). Multiple ranges and multiple F- test. Biometric, 11: 1-42.

El-Badawi, A.Y. and R.I. El-Kady (2006). Effect of partial replacement of concentrates with sugar beet pulp on performance, carcass characteristics and energy utilization of growing sheep. Inter. J. Agri. And Biol., 8 (3): 344-348.

El-Badawi, A.Y.; M.H.M. Yacout and H.E.M. Kamel (2003). Effect of replacing corn with sugar beet pulp on ruminal degradation kinetics and utilization efficiency of rations by growing sheep. Egypt. J. Nutr. Feeds, 6: 1349-1363.

El-Badawi, A.Y.; R.I. El-Kady; T.M. El-Bedawy and M.Z. Sedik (2001). Inclusion of sugar beet pulp in ruminant diets. 2. Changes of rumen fermentation, microbial count and enzymatic activity associated with feeding different levels of ureated sugar beet pulp in rations of growing sheep. Egypt. J. Nutr. Feeds, 4: 113-24.

El-Sokkary, G.H.and E.A. Awadalla (2011). The protective role of vitamin C against cerebral and pulmonary damage induced by cadmium chloride in male adult albino rat. Open Neuroendocrinol. J., (4):1-8.

El-Tohamy, M.M; A.M. Hamam and U.A. Ali (1997). Reproductive efficiency of buffalo-cows and its relationship with some heavy metals in the soil. Egyp. J. Appl. Sci., 12: 75-88.

FAO (2007). Joint FAO/WHO Food Standard Programme Codex Alimentarius Commission 13th Session. Report of the Thirty Eight Session of the Codex Committee on Food Hygiene, Houston, United States of America, ALINORM 07/30/13.

Farid, S. and M.K. Baloch (2012). Heavy metal ions in milk samples collected from animals feed with city effluent irrigated fodder. J. Gree. Phys. Sci., 2 (2): 36-43.

Galatov, A.N. (1994). The effect of crossbreeding on milk production of fine wool ewes. Animal Breed Abst., 62: 211.

Ghorbe, F.; M. Bouzelbene; A.F. Makni; F. Guermazi; A. Kammoun and J. Murat (2001). Effect of chronic lead exposure on kidney function in male and female rats: determination of lead exposure biomarkers. Archive of Physiology and Biochemistry, 109: 457-463.

Goiri, I.; A. Garcia-Rodriguez and L.M. Oregui (2008). Effect of chitosans on in vitro rumen digestion and fermentation of maize silage. Anim. Feed Sci. Technol., doi:10.1016/j.anifeedsci.2008.04.007.

Goiri, I.; A .Garcia-Rodriguez and L.M. Oregui (2009a). Effect of chitosans on in vitro rumen digestion and fermentation of maize silage. Anim. Feed Sci. Technol ., 148: 276-287.

Goiri, I.; A. Garcia-Rodriguez, L.M. Oregui (2009b). Effect of chitosan on mixed ruminal microorganism fermentation using the rumen simulation technique (Rusitec). Anim. Feed Sci. Technol., 152: 92-102.

Goiri, I.; L.M. Oregui and A. Garcia-Rodriguez (2009c). Dose-response effects of chitosans on in vitro rumen digestion and fermentation of mixtures differing in forage-to-concentrate ratios. Anim. Feed Sci. Technol., 151: 215-227. 


\section{Hassan et al.}

Goiri, I.; L.M. Oregui and A.Garcia-Rodriguez (2010). Use of chitosans to modulate ruminal fermentation of a 50:50 forage - to concentrate diet in sheep. J Anim Sci., 88: 749-755.

Goyer, R.A. and M.G. Cherian (1979). Ascorbic acid and EDTA treatment of lead toxicity in rats. Life Sci., (24): 433-438.

Guibal, E. (2004). Interactions of metal ions with chitosan-based sorbents: A review. Sepa. and Puri. Tech., 38: 43-74.

Hagemeister, H.; W. Lipping and W.K. Kaufimann (1981). Microbial protein synthesis and digestion in the high yielding dairy cow. In Recent Advances in Animal Nutrition. Hresign, PP. 67. Butterworth, London.

Han, K.N.; I.K. Kwon; J.D. Lohakare; S. Heo and B.J. Chae (2007) .Chito-oligosaccharides as an alternative to antimicrobials in improving performance, digestibility and microbial ecology of the gut in weanling pigs. Asian-Aust. J. Anim. Sci., (20)4: 556 - 562.

Haneef, S.S.; D. Swarup; S.K. Dwivedi and P.K. Dash (1998). Effects of concurrent exposure to lead and cadmium on renal function in goats. Small Ruminant Research, 28: 257-261.

Harel, P.; L. Mignot; J.P. Sauvage and G. A. Junter (1998). Cadmium removal from dilute aqueous solution by gel beads of sugar beet pectin. Ind. Crop. Prod. 7:239-247.

Hashem, A.; E. Abdel-Halim; H.A. Maauof; M.A. Ramadan and A. Abo-Okeil (2007). Treatment of sawdust with polyamine for wastewater treatment. J. Ener. Edu. Sci. Technol., 19: 45-58.

Hassan, Z.; Z. Anwar; K. U. Khattak; M. Islam; R. Ullah Khan and J. Z. Khan Khattak (2012). "Civic Pollution and Its Effect on Water Quality of River Toi at District Kohat, NWFP”, Research Journal of Environmental and Earth Sciences, vol 4, 5.

Hayashi, A.; A.C. Gillen and J.R. Lott (2000). Effects of daily oral administration of quercetin chalcone and modified citrus pectin on implanted colon-25 tumor growth in Balb-c mice. Altern. Med. Rev., 5: 546- 552.

Henry, J.B. and S.D. Todd (1974). Clinical Diagnosis and Measurement by Laboratory Methods, 16th Ed., W. B. Saunders and Co., Phliadephia., PA. PP. 260.

Henry, R.J.; D.C. Cannon and J.W. Winkelman (1974). Clinical Chemistry: Principles and Techniques, 11th Ed., Happer and Row Publishers PP. 1629.

Holzer, Z.; D. Levy and V. Samule (1986). Interactions between supplementary nitrogen source and ration energy density on performance and nitrogen utilization in growing and fattening male cattle. Animal Production, 42: 19.

Huang, T.W.; Y.H. Young; P.W. Cheng; Y.H. Chan and T.H. Young (2009).Culture of nasal epithelial cells using chitosan-based membranes. Laryngoscope, 119: 2066-2070.

Jayathilakan, K.; K. Sultana; K. Radhakrishna and A. S. Bawa (2012). Utilization of byproducts and waste materials from meat, poultry and fish processing industries: a review. J. Food Sci. Technol., 49(3):278-293.

Jeon, Y.J.; P.J. Park and S.K. Kim (2001): Antimicrobial effect of chitooligosaccharides produced by bioreactor. Carbohydrate Polymer, 44: 71-76.

Jones J.B. and V.W. Case (1990). Sampling and handling and analyzing plant tissues samples. In: Westerman K.L. (ed), Soil testing and plant analysis (3rd edition). Soil Science Society and America, Madison: 389-427.

Khan, T.A; M. Mazid and F. Mohammad (2011). A review of ascorbic acid potentialities against oxidative stress induced in plants. J Agrobiol., 28(2): 97-111.

Knorr, D. (1984). Use of chitinous polymers in food - A challenge in food research and development. Food Technology, 38: 85-97.

Kolacz, R.; Z. Dobrzanski and E. Bodak (1996). Bioaccumulation of Cd, $\mathrm{Pb}$ and $\mathrm{Hg}$ in animals tissues (in Polish). Med. Wet., 52 (11): 686. 


\section{Hassan et al.}

Lanza, M.; A. Priolo; L. Biondi; M. Bella and H.B. Salem (2001). Replacement of cereal grains by orange pulp and carob pulp in faba bean-based diets fed to lambs: effects on growth performance and meat quality. Anim. Rese., 50 (1): 21-30.

Lawes, S. (1993). Analysis of heavy metal-contaminated soil and anaerobically digested sewage sludge. BSc Thesis, Department of Agricultural Chemistry and Soil Science, University of Sydney.

Makkar, H.P.; O.P. Sharma; R.K. Dawra, and S.S. Negi (1982). Simple determination of microbial protein in rumen liquor. J. Dairy Sci., 65: 2170-2173.

Mansfield, H.R.; M.D. Stern and D.E. Otterbye(1994). Effects of beet pulp and animal by-products on milk yield and in vitro fermentation by rumen microorganisms. J. Dairy Sci., 77: 205-216.

Mason, C.F. (2002). Biology of freshwater pollution. $4^{\text {th }}$ ed. Essex Univ. England. pp 387.

Mata, Y.N.; M.L. Blazquez; A. Ballester; F. Gonzlez and J.A. Muanoz (2009). Sugar-beet pulp pectin gels as biosorbent for heavy metals: Preparation and determination of biosorption and desorption characteristics. J. Chem. Engi., 150: 289-301.

Maynard, L.A.; U.K. Loosli; H.F. Hintz and R.G. Warner (1978). Animal Nutrition. (7th Ed.) Mcgraw. Hill Book Co., New York.

Monkiewicz, J.; H. Geringer and J. Nicpon (1994). Influence of specific environmental threat on cows housing in cooper industry region (in Polish). Med. Wet., 50 (4): 162.

Mousa, M.R.M. (2011). Effect of partial replacement of dietary concentrate feed mixture by fodder beet roots on productive performance of ewes and doe goats under the conditions of North Sinai. Asian J. Anim. Sci., 5: 228-242.

Nomanbhay, S.M. and K. Palanisamy (2005). Removal of heavy metal from industrial wastewater using chitosan coated oil palm shell charcoal. Elec. J. of Biotech., 8 (1):43-53.

Nouri, J.; B. Lorestani; N. Yousefi; N. Khorasani; A.H. Hasani; S. Seif and M. Cheraghi (2011). Phytoremediation potential of native plants grown in the vicinity of Ahangaran lead-zinc mine (Hamedan, Iran). Environ. Earth Sci., 62 (3): 639-644.

NRC (2007). Nutrient requirements of small ruminants: sheep, goats, cervids, and New World camelids. National Research Council of the National Academies, National Academies Press, Washington, D C, USA.

Olfaz, M.; N. Ocak; G. Erener; M.A. Cam and A.V. Garipoglu (2005). Growth, carcass and meat characteristics of Karayaka growing rams fed sugar beet pulp, partially substituting for grass hay as forage. Meat Sci., 70: 7-14.

Omer, H.A.; S.S. Abdel-Magid; A.Y. El-Badawi; I.M. Awadalla; M.I. Mohamed and M.S. Zaki (2013). Nutritional Impact for the Whole Replacement of Concentrate Feed Mixture by Dried Sugar Beet Pulp on Growth Performance and Carcass Characteristics of Ossimi Sheep. J. Life Sci., 10(4): 1987-1999.

Py's J. (1999). Trace elements in fodder plants, food dose and cow's milk in sulphur industry region (in Polish). Zesz. Nauk. AR Krakow, nr 253, Rozpr. Hab.

Razdan, A. and D. Pettersson (1994). Effect of chitin and chitosan on nutrient digestibility and plasma lipid concentrations in broiler chickens. Br. J. Nutr., 72:277-288.

Reddad, Z.; C. Gerente; Y. Andres; M. Ralet; J. Thibault and P.L.Cloirec (2002). Ni (II) and Cu (II) binding properties of native and modified sugar beet pulp.Carbohydrate Polymers, 49:23-31.

Reitman, S. and S.A. Frankel(957). Colorimetric method of determination of serum glutamic oxaloacetic and glutamic pyrovic transaminases. Am. J. Clin. Pathol., 28: 56-63.

Rozso, K.; J. Varhegyi; A.R. Mocsenyi and K. Fugli (2003). Lead content of the forages and the effect of lead exposure on ruminants. Vet. Bull., 73: 510-520.

SAS. (2004). User guide, version 9.1.2. Statistical Analysis System Institute Inc. USA

Schiewer, S. and S.B. Patil (2008). Pectin-rich fruit wastes as biosorbents for heavy metal removal: equilibrium and kinetics. Bioresour Technol., 6:1896-903. 


\section{Hassan et al.}

Shi, B.L.; D.F. Li; X.S. Piao and S.M. Yan (2005). Effects of chitosan on growth performance and energy and protein utilisation in broiler chickens. Br. Poult. Sci., 46(4): 516-519.

Silke S. and B. Ankit (2009). Biosorption of $\mathrm{Pb}^{2+}$ by original and protonated citrus peels: Equilibrium, kinetics, and mechanism, Chemical Engineering Journal, 146: 211-219.

Singh P. and R. Nagendran (2014). A comparative study of sorption of chromium (III) onto chitin and chitosan. Appl. Water Sci., DOI 10.1007/s13201-014-0218-2.

Singh, A.; T.K. Bhat and O.P. Sharma (2011). Clinical Biochemistry of Hepatotoxicity. J. Clin. Toxi., S:4. http://dx.doi.org/10.4172/2161-0495.S4-001. ISSN: 2161-0495.

Sorathiya, L.M.; M.D. Patel; K.K. Tyagi; A.B. Fulsoundar and A.P. Raval (2015). Effect of sugar beet tubers as a partial replacer to green fodder on production performance and economics of lactating Surti buffaloes in lean period. Veterinary World, Veterinary World, 8(1): 15-18.

Steel, R.D. and J.H. Torrie (1980). Principals and Procedures of statistics: A biometrical approach 2nd Ed., McGraw Hill Book Company, New York, USA. Pp. 137.

Stein, E.A. (1986). Textbook of Clinical Chemistry, NW Tietz, ed. W.B. Saunders, Philadelphia, pp. 879886.

Sugano, M.; W. Watanabe; A. Kishi; M. Izume and A. Ohtakara (1988). Hypochole-sterolemic action of chitosan with different viscosities in rats. Lipids, 23:187-191.

Sutton, J.D.; R. Knight, A.B. Mc Allan and R.H. Smith (1983). Digestion and synthesis in the rumen of sheep given diets supplemented with free and protected oils. Birth. J. Nutr., 49: 419-432.

Tagari, H.; Y. Driori; L. Ascarelli and A. Bondi (1964). The influence of level of protein and starch in rations for sheep on utilization of protein. Br. J. Nutr., 18: 333.

Trinder, P. (1969). Determination of glucose in blood using glucose oxidase with an alternative oxygen acceptor. Ann. Clin. Biochem., 6: 24-27.

Van Soest, P.J.; J.B. Robertson and B.A. Lewis (1991). Methods for dietary fiber, neutral detergent fiber and non starch polysaccharides in relation to animal nutrition. J. Dairy Sci., 74: 3583-3597.

Walsh, L.M. (1971). Instrumental methods for analysis of soils and plant tissue. Soil sci. Am. Inc. Madison. WI.

Warner, C.I. (1964). Production of volatile fatty acids in the rumen, methods of measurements. Nutr. Abstr. Rev., 34: 339.

Wenshui X.; P. Liu; J. Zhang and J. Chen (2010). Biological activities of chitosan and chitooligosaccharides. Food Hydrocolloids. pp 1-10.

World Health Organization (2006). WHO Guidelines for the Safe Use of Wastewater, Excreta and Greywater, vol. II, Wastewater Use in Agriculture, Geneva, World Health Organization.

Zaki, S.M.; M.A. Saad; A.H. Hamam; S.B. Faten and M.N. Shalaby (2001). Effect of Oral Administration of Lead Acetate on Some Biochemical and Hormonal Parameters During Pregnancy in Baladi Goats. Egyp. J. Comp. Path. and Clin.Path., 14: 29-35.

Zgurschi, G.; A. Păunescu; C. Ponepal; O. Drăghici and A. Marinescu (2013). A protective effect of thiourea against lead toxicity of the european chub, LEUCISCUS CEPHALUS. Buletinul AGIR, Supliment 1/2013:186 - 188.

Zwain, H. M.; M. Vakili and I. Dahlan (2014).Waste material adsorbents for zinc removal from wastewater: A comprehensive review. J. Inte. Chem. Engi., ID 347912, 13pages. http://dx.doi.org/10.1155/2014/347912. 


\section{Hassan et al.}

\section{الكيتوزان و البكتين وفيتامين سى كوسيله لإزالة العناصر الثقيله من العلائق وتأثير ذلك على أداء الماعز.}

أيمن عبد المحسن حسن 1، محمد سمير محمود خليل، عمرو محمد حلمى شويرب1، محمد حلمى ياقوت1، حسين محمد

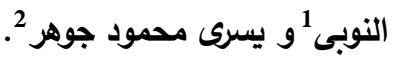

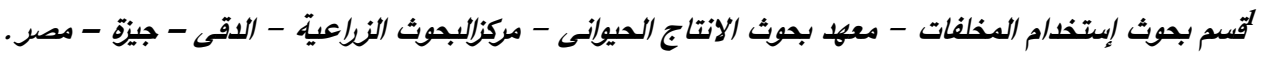

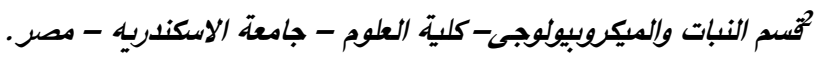

فيى تجربه لمعرفة نأثير الكينوزان، البكتين، وفيتامين سى كوسيله لإزالة المعادن الثقيله من علائق الماعز وتأثير ذلك على الأداء الإنتاجى فقد تم دراسة أربعة علائق:

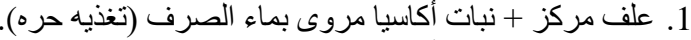

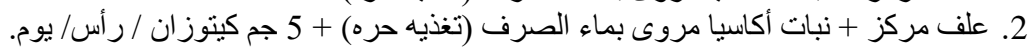

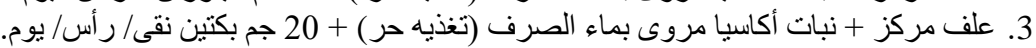

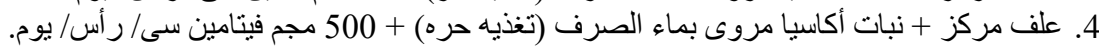

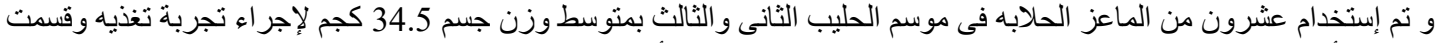

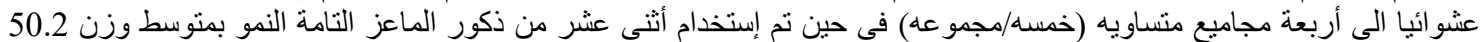

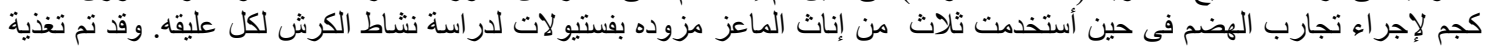
الاكاسيا حتى الثبع مع إضافة العلف المركز بكميات محدده لكى تغطى 50\% من أحتياجات البروتين الخام فى العلائق. وقد أظهرت

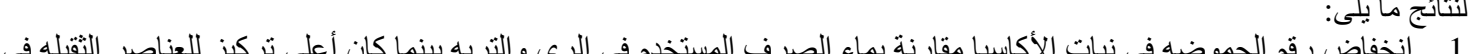

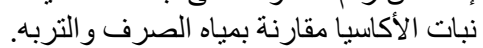

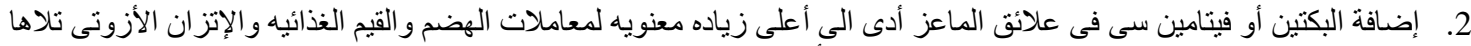

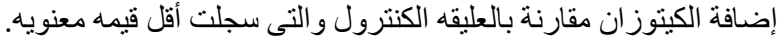

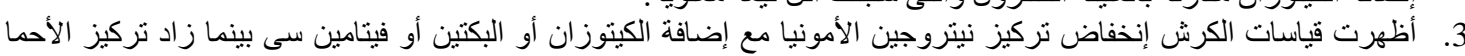

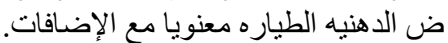

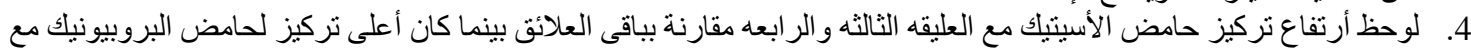

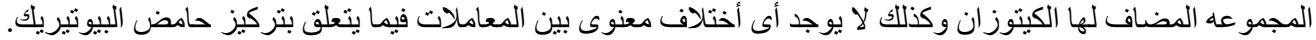

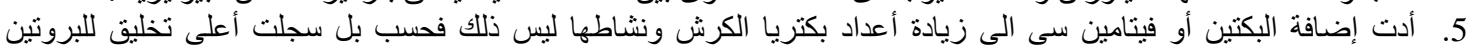

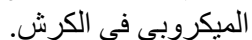
6. لوحظ زيادة إنتاج اللبن مع المجاميع المضاف إليها الكيتوز ان أو البكتين أو فيتامين سى مقارنة بالمجمو عه الكنترول وفى نفس الوقت

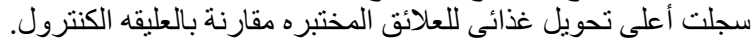

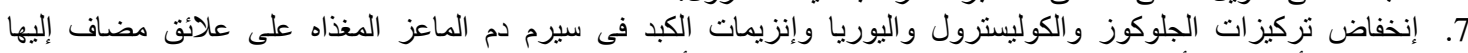

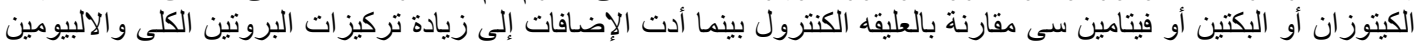
و الجلوبيولين. 8. أظهرت بقاين المعادن الثقله فى روث الماعز قيم عاليه مع مجاميع الكيتوزان أو البكتين أو فيتامين سى بينما كانت أقل قيم لبقايا

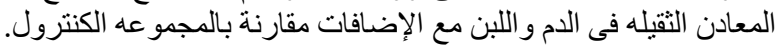

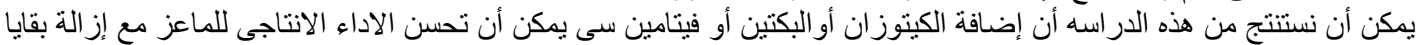

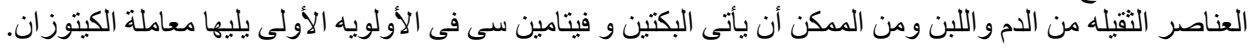

